\title{
Effects of PNU157706, a dual 5a-reductase inhibitor, on gene expression in the rat epididymis
}

\author{
N A Henderson ${ }^{1}$, G M Cooke C $^{3,4}$ and B Robaire ${ }^{1,2}$ \\ ${ }^{1}$ Department of Pharmacology and Therapeutics, McGill University, Montreal, Quebec, Canada \\ ${ }^{2}$ Department of Obstetrics and Gynecology, McGill University, Montreal, Quebec, Canada \\ ${ }^{3}$ Toxicology Research Division, Health Products and Foods Branch, Food Directorate, Health Canada, Ottawa, Ontario, Canada \\ ${ }^{4}$ Reproductive Biology Unit and Departments of Cellular and Molecular Medicine, and Obstetrics and Gynecology, University of Ottawa, \\ Sir Frederick G Banting Research Centre, Ottawa, Ontario, Canada \\ (Requests for offprints should be addressed to B Robaire, Department of Pharmacology and Therapeutics, McGill University, \\ 3655 Promenade Sir William Osler, Montreal, Quebec, Canada H3G 1Y6; Email: brobaire@pharma.mcgill.ca)
}

\begin{abstract}
The epididymis is the site of sperm maturation and storage. $5 \alpha$-Reductases (types 1 and 2) are key enzymes in this tissue because they convert testosterone to dihydrotestosterone (DHT), the main androgen regulating epididymal functions. Examining the consequences of inhibiting DHT formation is likely to provide important information regarding the regulation of epididymal functions, yet few inhibitor studies have focused on this tissue. To understand better DHT-mediated regulation of epididymal gene expression, we employed a dual $5 \alpha$-reductase inhibitor and cDNA microarrays to examine the effects of $5 \alpha$-reductase inhibition on gene expression in the initial segment, caput, corpus, and cauda epididymidis. Inhibition of epididymal $5 \alpha$-reductase activity by PNU157706 was confirmed by in vitro enzyme assays. Rats were treated with $0,0 \cdot 1,1 \cdot 0$ or $10 \mathrm{mg} / \mathrm{kg}$ per day PNU157706 for 28 days. The weights of DHT-dependent tissues,
\end{abstract}

including the epididymis, were decreased following treatment. The effect of treatment on gene expression was dose-dependent and highly segment-specific. The initial segment responded uniquely in that a similar number of genes increased and decreased in expression compared with the other segments where the majority of affected genes decreased in expression. Some of the more dramatically affected genes were involved in signal transduction as well as fatty acid and lipid metabolism, regulation of ion and fluid transport, luminal acidification, oxidative defense and protein processing and degradation. These are essential processes contributing to the formation of an optimal luminal microenvironment required for proper sperm maturation. These results provide a novel insight into the DHT-dependent mechanisms that control epididymal functions.

Journal of Endocrinology (2004) 181, 245-261

\section{Introduction}

The epididymis is a single, highly convoluted tubule that receives the input of sperm and fluid from the testis and that empties into the vas deferens (Robaire \& Hinton 2002). It is structurally divided into four main segments (initial segment, caput, corpus and cauda epididymidis) and functions in the transport, protection, maturation and storage of spermatozoa (Orgebin-Crist 1967, Robaire \& Hinton 2002). The multifaceted sperm-related functions of the epididymis have made this tissue an appealing target for the control of male contraception and fertility. Achieving these therapeutic goals, however, necessitates a greater understanding of the mechanisms regulating epididymal structure and functions.

Not surprisingly, given the complexity of this tissue, many factors are involved in the regulation of epididymal functions, including estrogens, retinoids, growth factors and unidentified testicular factors (Hinton et al. 1998, Lan et al. 1998, Hess et al. 2002, Orgebin-Crist et al. 2002). Androgens, however, are recognized as the primary hormonal regulators of epididymal structure and functions (Blaquier et al. 1972, Orgebin-Crist \& Tichenor 1973). Furthermore, several in vivo and in vitro studies have confirmed that it is not testosterone, but rather dihydrotestosterone (DHT), that is the main androgen acting in this tissue (Gloyna \& Wilson 1969, Tindall et al. 1972, Orgebin-Crist et al. 1976, Turner et al. 1984). $5 \alpha$-Reductase (EC 1.3.1.22) is thus a key enzyme in the epididymis because of its role in locally converting testosterone to DHT. Two isoforms of $5 \alpha$-reductase have been identified and are termed type 1 and type 2 (Andersson \& Russell 1990, Normington \& Russell 1992). Both isoforms are present in the epididymis and are differentially expressed along the tubule (Viger \& Robaire 1996). 
Examining the consequences of inhibiting DHT formation is likely to provide important information regarding the regulation of epididymal functions, yet very few inhibitor studies have focused on this tissue (de Larminat \& Blaquier 1979, Cohen et al. 1981, Cooke \& Robaire 1986, Zoppi et al. 1992). In order to elucidate specific functions of $5 \alpha$-reductase in the epididymis using inhibitors, compounds that are specific only to $5 \alpha$-reductase and that inhibit both isoforms of the enzyme (i.e. dual inhibitors) are required. The latter is necessary as it has not yet been determined if one or both of the isoforms are important for mediating the androgen regulation of epididymal structure and functions. Specificity and toxicity were problems with early compounds such as diethyl-4-methyl-3-oxo-4-aza-5 alpha-androstane-17 beta-carboxamide (4-MA) (Cooke \& Robaire 1986, DiSalle et al. 1994). Modification of 4-MA yielded finasteride, the first clinically available $5 \alpha$-reductase inhibitor (Sudduth et al. 1993, Li et al. 1995, Steers 2001). With the discovery of two isoforms of $5 \alpha$-reductase, it was shown that finasteride is selective for the type 2 isoform. The lack of specificity of finasteride for the type 1 isoform has been proposed as the reason why this drug is only moderately effective in the treatment of benign prostatic hyperplasia (Steers 2001, Bartsch et al. 2002). Drug development efforts to create more therapeutically effective compounds for the treatment of androgendependent disorders such as benign prostatic hyperplasia have provided compounds that fulfill the requirements of specificity and dual action. PNU157706 is a novel dual $5 \alpha$-reductase inhibitor for the potential treatment of benign prostatic hyperplasia (di Salle et al. 1998). It is more potent than finasteride in decreasing DHT levels. This compound is of express interest as it has been reported to have an effect on epididymal weight (di Salle et al. 1998).

Hormones often effect changes in their target tissues by altering the expression of specific sets of genes. The expression patterns of several epididymis-specific and/or epididymis-relevant genes have been analyzed along the epididymis (for review see Cornwall et al. 2002); however, understanding the structure and function of this complex tissue requires more than analyzing the properties of isolated genes. The biological function of sperm maturation arises from the interactions of many components. cDNA array technology provides a powerful method for large-scale, parallel gene expression analysis that can provide insight into these interactions, and how they are regulated. Our objective in this study was to use cDNA array technology in combination with a novel $5 \alpha-$ reductase inhibitor to help elucidate the DHT-dependent regulatory networks that govern segment-specific gene expression in the epididymis. We demonstrate that the inhibition of DHT formation in the epididymis alters the expression of many genes potentially involved in sperm-related functions. Furthermore, the present studies indicate that DHT-dependent regulation of gene expression is highly segment-specific and involves components of different signaling pathways.

\section{Materials and Methods}

\section{Animals}

Adult male Sprague-Dawley rats (325-350 g) were obtained from Charles River Canada (St Constant, QC, Canada), maintained under controlled light (14 h light: $10 \mathrm{~h}$ darkness) and temperature $\left(22^{\circ} \mathrm{C}\right)$, and freely provided with food and water. Caput-corpus epididymides from 90-day-old animals that were previously stored at $-80{ }^{\circ} \mathrm{C}$ were used for in vitro enzyme assays. For the in vivo study, rats were randomly divided into four groups of five animals each and gavaged with $0.5 \mathrm{ml} / \mathrm{kg}$ of 0 (control), $0 \cdot 1$ (low), $1 \cdot 0$ (medium) or $10 \mathrm{mg} / \mathrm{kg}$ (high) PNU157706 (generously provided as a gift by Pharmacia \& Upjohn, Italy) suspended in $0 \cdot 5 \%$ methylcellulose solution (BDH, Montreal, QC, Canada) containing 0.4\% Tween 80 (A\&C American Chemicals Ltd, Montreal, QC, Canada) for 28 consecutive days. Doses were selected based on reported effects on rat ventral prostate; the dosing regimen with $10 \mathrm{mg} / \mathrm{kg}$ per day PNU157706 has been shown to decrease prostatic DHT levels by $>90 \%$ (di Salle et al. 1998). At killing, animals were anesthetized and seminal vesicles, testes, ventral prostates and epididymides from the left side were collected. Epididymides were sectioned into initial segment, caput, corpus and cauda, and immediately frozen in liquid nitrogen. Tissues were stored at $-80{ }^{\circ} \mathrm{C}$ until used for RNA extraction. All animal studies were conducted in accordance with the principles and procedure outlined in the Guide to the Care and Use of Experimental Animals prepared by the Canadian Council on Animal Care.

\section{Statistical analysis}

One-way ANOVA followed by Tukey's test was used to detect significant effects of PNU157706 treatment on tissue weights. The level of significance was taken as $P<0 \cdot 05$.

\section{In vitro $5 a$-reductase assays}

Unlabeled steroids were purchased from Steraloids Inc. (Newport, RI, USA). $\left[1,2,6,7-{ }^{3} \mathrm{H}\right]$ testosterone $(74 \cdot 0 \mathrm{Ci} /$ mmol) was from Dupont/NEN (Boston, MA, USA). Organic solvents were from BDH. Dimethylglutaric acid (DMG), NADPH and dimethylsulfoxide (DMSO) were from Sigma Chemical Co. (St Louis, MO, USA). Plasticcoated Whatman PE SIL G silica gel chromatography plates were purchased from Chromatographic Specialties (Montreal, QC, Canada). PNU157706 solutions were prepared in DMSO. 
Frozen caput-corpus epididymides (only normal, untreated tissues were used) were thawed, homogenized (Polytron) in DMG buffer (50 mM DMG, 5\% glycerol, $\mathrm{NaOH}, 0.5 \mathrm{mM}$ NADPH) $\mathrm{pH} 6.5$, and the nuclear and microsomal fractions were assayed for $5 \alpha$-reductase activity as previously described (Cooke \& Robaire 1987); protein was estimated using the method of Lowry et al. (1951). Initial studies were done to determine the linearity of nuclear and microsomal activity with time and protein concentration (data not shown). Purification and quantification of steroids was by thin-layer chromatography and scintillation counting (Cooke \& Robaire 1987). Reaction rates were obtained by linear regression analysis $(r>0.97)$. At $\mathrm{pH} 4 \cdot 5$, no $5 \alpha$-reductase activity was measurable at any concentration of testosterone.

Kinetic studies of $5 \alpha$-reductase activity were done at $\mathrm{pH} 6.5$ with testosterone (nine concentrations ranging from 5 to $375 \mathrm{nM}$ ). To determine the effects of PNU157706 on $5 \alpha$-reductase activity, PNU157706 was included at concentrations of $0,1,3$ and $10 \mathrm{nM}$. A single incubation time of $1 \mathrm{~h}$ and an incubation volume of $1 \mathrm{ml}$ were used in kinetic studies. To obtain the apparent Michaelis constant $\left(K_{\mathrm{m}(\mathrm{app})}\right)$ and apparent maximum velocity $\left(V_{\max (\mathrm{app})}\right)$, the Wilkinson method (non-linear least squares analysis of a rectangular hyperbola (Wilkinson 1961)) was used. Slope and intercept replots were obtained from, respectively, $K_{\mathrm{m}(\mathrm{app})} / V_{\max (\mathrm{app})}$ vs [I] and $1 / V_{\max (\mathrm{app})}$ vs [I]. Linear regression analysis of the replots was employed to determine the $K_{\mathrm{i}(\mathrm{app})}$ values.

\section{RNA extraction}

Total RNA was extracted from each sample using guanidine thiocyanate as described previously (Jervis \& Robaire 2001). Following isolation, RNA samples were DNase treated (Atlas Pure Isolation Kit User Manual, Section IV; Clontech, Palo Alto, CA, USA) to remove contaminating genomic DNA and RNA concentration was assessed by optical density determination at $260 \mathrm{~nm}$ (DU7 spectrophotometer; Beckman, Montreal, Quebec, Canada). In addition to spectrophotometric readings, RNA quality was verified by gel electrophoresis. Each sample consisted of a single epididymal segment obtained from individual rats; no tissues were pooled.

\section{cDNA arrays and hybridization}

RNA samples were used to probe cDNA arrays (Atlas Rat $1 \cdot 2 \mathrm{~K}$; Clontech) according to the manufacturer's instructions. Five arrays per epididymal segment per treatment group (control, low, medium and high PNU157706) were probed and referred to as replicates $(n=5 /$ treatment/ segment), with the following exceptions: four replicates per group were used ( $n=4$ /group) for the initial segment in the high PNU157706 group, the initial segment and cauda in the medium PNU157706 group and the initial segment and caput in the low PNU157706 group; three arrays were used ( $n=3$ /group) for the corpus in the medium PNU157706 group. A total of 75 arrays were screened for this experiment. Arrays were exposed to phosphorimager plates (Molecular Dynamics, Sunnyvale, CA, USA) $24 \mathrm{~h}$ before scanning with a phosphorimager (Storm; Molecular Dynamics). Analysis of array images with Atlas Image (Version 2.0; Clontech) was performed to quantify the intensity of each cDNA spot, which reflects the relative abundance of RNA in the sample. The raw data for each gene (intensity minus the background) were imported into Genespring 4·0.7 (Silicon Genetics, Redwood, CA, USA) for further analysis. For each replicate array in a given treatment group, a gene was considered detected if its intensity was above threshold, with threshold defined as two times the average background of that individual array. A gene was considered expressed if it was detected in at least three replicates in that group.

To minimize experimental variation and allow for comparison of different treatment groups, data were normalized with the standard experiment-to-experiment normalization (Genespring). Specifically, the median level of expression on each array was defined as 1 and expression of each gene was normalized relative to 1 ; this value was averaged for all replicates in a group to generate what is referred to as the relative intensity for a given gene. All individual gene profiles are shown using the standard experiment-to-experiment normalization. Gene expression changes of 2 -fold or greater (i.e. $50 \%$ decrease or $100 \%$ increase) are focused on throughout the text except for genes belonging to specific gene families. The importance of replication for validation of gene expression studies has been documented (Lee et al. 2000, Herwig et al. 2001). Conventional statistical analysis was not applicable to our large normalized data sets. We include errors of the mean (S.E.M.) of individual genes to show variability among replicates in a given group.

As a means to validate our gene array expression data, we examined the control expression profiles of three genes with well-established epididymal expression profiles (Fig. 1). As expected, the expression of $5 \alpha$-reductase type 2 was highest in the initial segment and caput epididymidis, angiotensin-converting enzyme expression peaked dramatically in the caput epididymidis in comparison with the other segments, and androgen receptor gene expression remained constant throughout the epididymis (Strittmatter \& Snyder 1984, Robaire \& Viger 1993, Viger \& Robaire 1996).

\section{Results}

\section{Tissue weights}

There were no significant changes in body weights among any of the groups of animals (data not shown). As expected, the weights of the seminal vesicle and ventral 


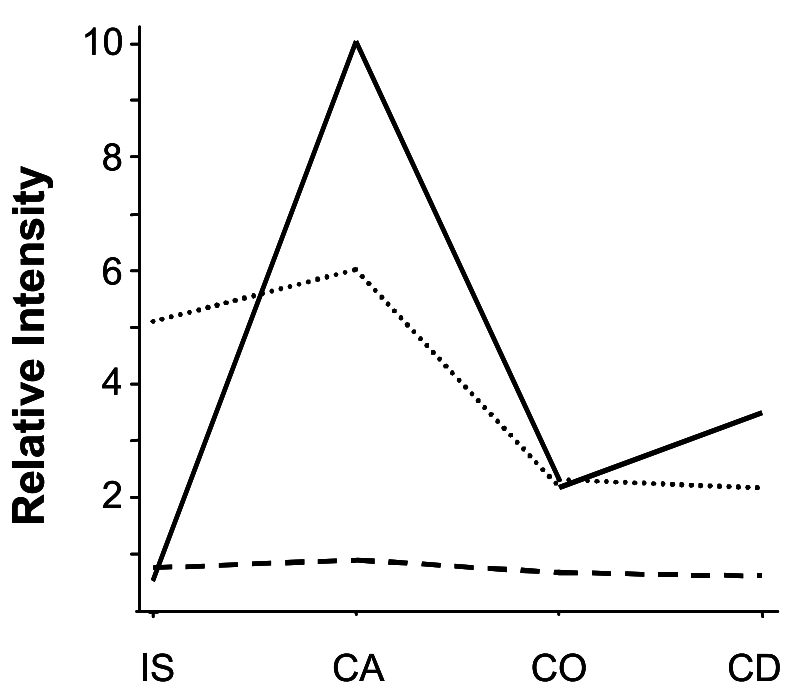

Figure 1 Relative expression of $5 \alpha$-reductase type 2 (dotted line), angiotensin-converting enzyme (solid line) and androgen receptor (dashed line) in the initial segment (IS), caput (CA), corpus (CO) and cauda $(C D)$ epididymidis of vehicle-treated (control) rats. Gene expression is presented as relative intensity (means \pm S.E.M., 3-5 replicates/group).

prostate, both DHT-dependent tissues, were significantly decreased with all doses of PNU157706 while there was no effect of treatment on testis weights (Fig. 2A-C). A $10 \%$ decrease in epididymal weight was observed with the low and medium PNU157706 treatment groups with a further decrease to $82 \%$ of control in the high PNU157706 group (Fig. 2D).

\section{5a-Reductase activity}

The addition of PNU157706 to incubations at concentrations of $0,1,3$ and $10 \mathrm{nM}$ inhibited epididymal $5 \alpha$-reductase as shown in Fig. 3A (nuclear) and B (microsomal) fractions. Kinetic analyses demonstrated that PNU157706 caused the $K_{\mathrm{m}(\mathrm{app})}$ values to increase (about 3- to 4-fold) without affecting the $V_{\max (a p p)}$ values. Confirmation of these findings was achieved with slope $\left(K_{\mathrm{m}(\mathrm{app})} / V_{\max (\text { app })} \mathrm{vs}[\mathrm{I}]\right)$ and intercept $\left(1 / \mathrm{V}_{\max (\mathrm{app})} \mathrm{vs}[\mathrm{I}]\right)$ replots, shown in Fig. 3C (nuclear) and D (microsomal); the slopes of the replots were positive and the slopes of the intercept replots were almost horizontal or exhibited a negative slope. The values for the inhibition constant $\left(K_{\mathrm{i}(\mathrm{app})}\right)$ for PNU157706 from the slope replots were lower than those obtained from the intercept replots (Table 1) indicating that this drug is a competitive inhibitor of $5 \alpha$-reductase. Furthermore, since the $K_{\mathrm{i}}$ is lower than the $K_{\mathrm{m}(\mathrm{app}),}$ the affinity of $5 \alpha$-reductase for PNU157706 is greater than the affinity for testosterone.

\section{Number of genes expressed}

The expression of 1176 genes was examined simultaneously using cDNA arrays. In each epididymal segment, similar numbers of transcripts were detected in the control and high PNU157706 treatment groups. In the initial segment, transcripts for 34\% (397) and 31\% (368) of genes were detected in tissues from control and treated rats respectively. Similarly, in the caput epididymidis, transcripts for 35\% (411) of genes were detected in tissue from control animals and 31\% (360) in those from treated rats. A lower number of transcripts was detected in the corpus epididymidis compared with the other segments: $25 \%$ (295) of genes in control, 21\% (247) in treated. Slightly more transcripts were detected in the cauda epididymidis; $36 \%$ (420) of genes in control, 37\% (438) in treated.

\section{Overall changes in gene expression with PNU157706 treatment}

The range of gene expression changes in the initial segment following high PNU157706 treatment extended from a greater than $80 \%$ decrease (c-met proto-oncogene) to a $6 \cdot 6$-fold increase (set $\beta+$ set $\alpha$ isoform). In the caput epididymidis, the range was from a $73 \%$ decrease in expression (cathepsin B) to a 9.7-fold increase in expression (P2X purinoceptor 1). In addition to having the lowest number of genes with detected expression, the corpus epididymidis also demonstrated the smallest range of gene expression changes following treatment; expression changes ranged from a $78 \%$ decrease (carbonic anhydrase 4 (CA4)) to a $4 \cdot 8$-fold increase (muscarinic acetylcholine receptor M4). The largest range of gene expression changes was observed in the cauda epididymidis, which was from a greater than 90\% decrease (elastase 2) to a $7 \cdot 3$-fold increase (serine proteinase rPC7).

As expected, using the criterion of 2-fold changes in gene expression, i.e. a $100 \%$ increase or $50 \%$ decrease, the expression of a large proportion of genes was unaffected by PNU157706 treatment in each epididymal segment. Analysis of the number of genes undergoing a minimum 2 -fold change in expression between control and high PNU157706 treatment groups revealed a unique response to treatment in the initial segment (Fig. 4). In this segment, a similar number of genes increased and decreased in expression by 2 -fold or greater. In contrast, in more distal epididymal segments, there were more genes decreasing than increasing in expression by 2 -fold or more following treatment (Fig. 4).

\section{Segment-specific changes in gene expression}

A total of 81 genes changed in expression by 2 -fold or greater in the epididymis following treatment with high PNU157706. The expression of the majority of these genes was affected uniquely in one segment. The few transcripts that changed in expression by at least 2 -fold in more than one segment are indicated in Table 2. Transcripts of particular interest that changed in a segmentspecific manner were examined in the control, low, 
A

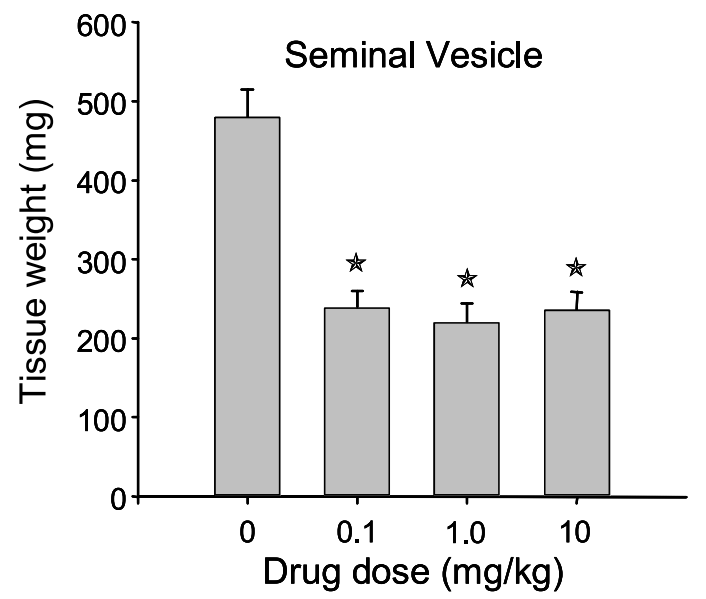

C

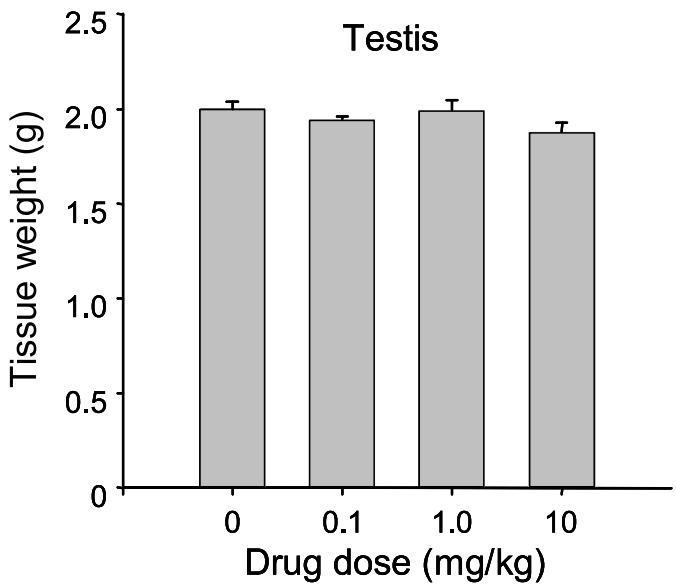

B

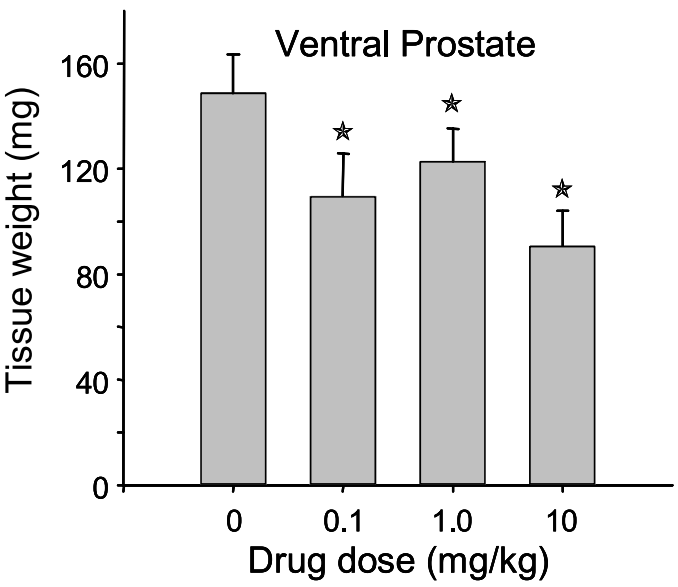

D

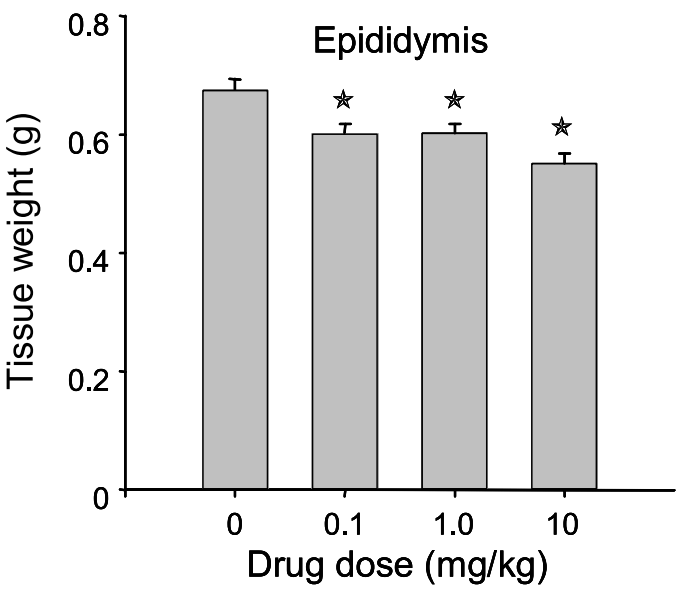

Figure 2 Effect of PNU157706 treatment on weights of seminal vesicles (A), left ventral prostates (B), testes (C) and epididymis (D). Data are represented as the means \pm S.E.M. for each treatment group on the $x$-axis: control, $0 \mathrm{mg} / \mathrm{kg}$ (0); low dose, $0 \cdot 1 \mathrm{mg} / \mathrm{kg}(0 \cdot 1)$; medium dose, $1 \cdot 0 \mathrm{mg} / \mathrm{kg}(1 \cdot 0)$; high dose, $10 \mathrm{mg} / \mathrm{kg}(10) .{ }^{*} P<0 \cdot 05$.

medium and high PNU157706 treatment groups in order to visualize dose-response profiles.

Initial segment A total of 25 transcripts changed by a minimum of 2 -fold in the initial segment. Differential expression was observed for four genes that are mediators or modulators of signal transduction (Fig. 5A). Two oncogenic proteins (NF-2, retinoblastoma protein pp105) and ras-GTPase activating protein (p120 GAP) decreased in expression. The maximum decrease was achieved only with the high dose of PNU157706. The fourth gene, Crk-associated substrate (CAS), a kinase substrate, showed increased expression with medium and high PNU157706 treatment. Another important group of transcripts affected in the initial segment were those involved in fatty acid/ lipid metabolism: fatty acid amide hydrolase, corticosteroid $11-\beta$ dehydrogenase 1 , very long chain acyl-CoA dehydrogenase (VLCAD) and 5-lipoxygenase (5-LO)
(Fig. 5B). Transcripts for these four genes increased following PNU157706 treatment. For the two dehydrogenases and fatty acid amide hydrolase, the maximum increase was observed with the low dose while for 5-LO, an increase in expression was only achieved with the high dose. Interestingly, two genes with roles in regulating ion and water balance in body fluids were also affected by PNU157706 treatment; atrial natriuretic peptide clearance (ANP-C) receptor expression decreased while chloride channel CLC-7 expression increased (Fig. 5C).

Caput Only 14 genes changed in expression by a minimum of 2-fold in the caput epididymidis. Specifically, the expression of three signaling genes was differentially affected by PNU157706 treatment (Fig. 6A). One transcript, cAMP-dependent protein kinase type II-beta regulatory chain (cAMP dep PK Type 11ß), showed a decrease only with the high dose of PNU157706. In contrast, 

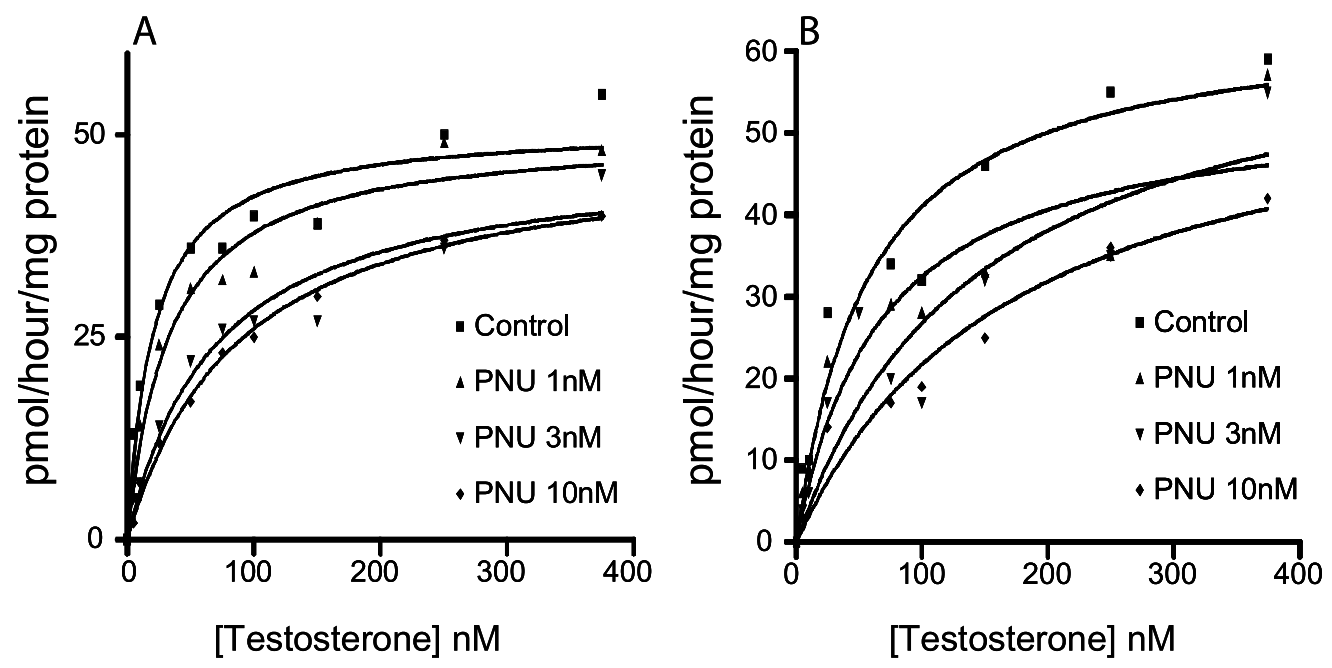

C
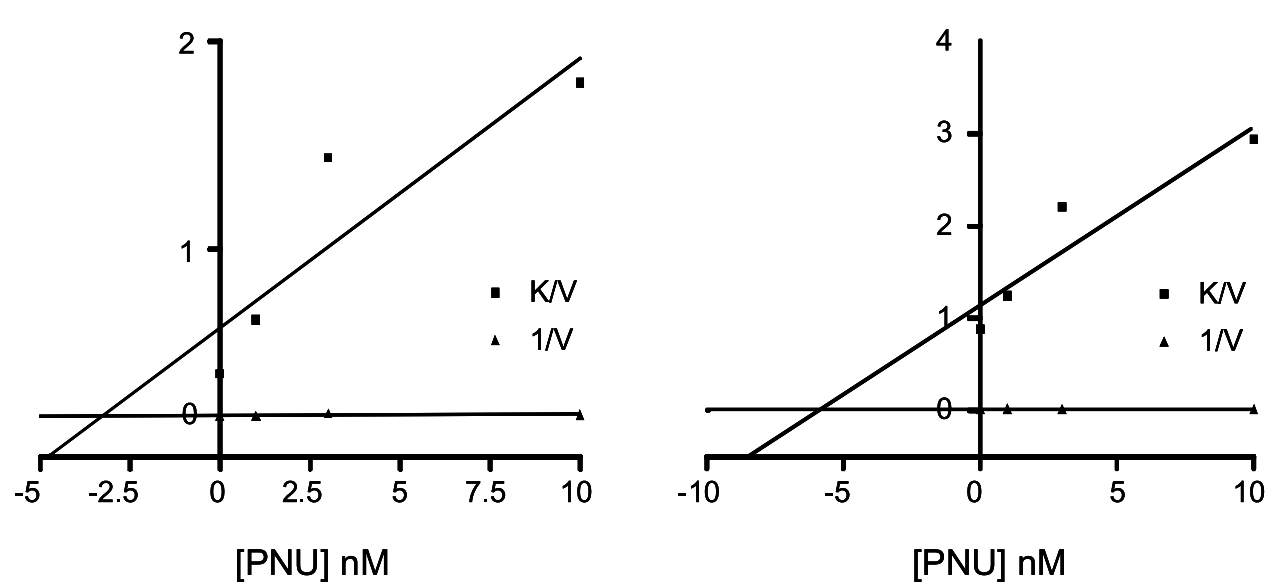

Figure 3 Inhibition of rat nuclear (A) and microsomal (B) $5 \alpha$-reductase activity in vitro by different concentrations of PNU157706 (PNU). For nuclear (C) and microsomal (D) 5a-reductase, slope replots (squares) were obtained from $K_{\mathrm{m}(\mathrm{app})} / V_{\max (\mathrm{app})} \mathrm{vs}$ [PNU] and intercept replots (triangles) were obtained from $1 / V_{\max (\text { app) }}$ vs [PNU].

Ehk 3, a tyrosine kinase, and neural thrombospondin 1-like protein (NELL-1), a protein kinase C (PKC)binding protein, both increased and the maximum effect was achieved with the low dose of PNU157706. Cathepsins, a family of cysteine proteases that function in protein degradation and processing, have been shown previously to change in expression in the epididymis under certain conditions (McGrath 1999, Jervis \& Robaire 2002, 2003). In the caput epididymidis, cathepsin B expression decreased following treatment only with the high dose of PNU157706 (Fig. 6B). Also of note in the caput epididymidis was the increase in expression of short chain acyl-CoA dehydrogenase (SCAD), another gene involved in fatty acid/lipid metabolism (Fig. 6C). As seen with other genes, the maximum increase in expression was obtained with the low dose of PNU157706. Other transcripts specifically affected by treatment in the caput epididymidis included two transforming growth factor- $\beta$ (TGF $\beta$ ) family members; TGF $\beta$ receptor 1 and TGF $\beta$ masking large subunit decreased maximally in expression with the low dose of PNU157706.

Corpus In the corpus epididymidis, 15 genes showed expression changes of 2-fold or greater. Of particular interest in this segment was the dose-dependent decrease in expression of CA4, a gene implicated in the acidification of the epididymal lumen (Fig. 7A). Three signaling-related genes also decreased in expression in a dose-dependent manner (Fig. 7B). These were ras-related protein rab13, a G-protein involved in trafficking and 
Table 1 Summary of the in vitro effect of PNU157706 on epididymal nuclear and microsomal 5a-reductase enzyme kinetics

Experiment 1

\begin{tabular}{|c|c|c|c|c|c|c|c|c|c|}
\hline$K_{\mathrm{m}(\mathrm{app})}$ & $V_{\max (a p p)}$ & $r$ & $K_{\mathrm{i}(\mathrm{app})}$ & $r$ & $K_{\mathrm{m}(\mathrm{app})}$ & $V_{\max (a p p)}$ & $r$ & $K_{\mathrm{i}(\text { app })}$ & $r$ \\
\hline $20 \cdot 5$ & $51 \cdot 1$ & 0.95 & - & - & $20 \cdot 7$ & $45 \cdot 7$ & $0 \cdot 86$ & - & - \\
\hline $33 \cdot 1$ & $50 \cdot 4$ & 0.97 & - & - & $40 \cdot 9$ & $48 \cdot 5$ & 0.93 & - & 一 \\
\hline $68 \cdot 7$ & $47 \cdot 8$ & 0.96 & - & - & $64 \cdot 4$ & $53 \cdot 5$ & 0.90 & - & - \\
\hline $88 \cdot 2$ & $49 \cdot 1$ & 0.99 & - & - & $96 \cdot 7$ & $48 \cdot 6$ & 0.96 & - & - \\
\hline - & - & - & $3 \cdot 13$ & $0 \cdot 90$ & - & - & - & $4 \cdot 02$ & 0.98 \\
\hline - & - & - & $74 \cdot 5$ & 0.51 & - & - & - & - ve & $0 \cdot 23$ \\
\hline $57 \cdot 1$ & $64 \cdot 4$ & 0.94 & - & - & $32 \cdot 4$ & $63 \cdot 9$ & 0.95 & - & 一 \\
\hline $67 \cdot 7$ & $54 \cdot 4$ & $0 \cdot 88$ & - & - & $62 \cdot 2$ & $64 \cdot 5$ & $0 \cdot 83$ & - & - \\
\hline $145 \cdot 3$ & $65 \cdot 7$ & 0.91 & - & - & $60 \cdot 8$ & $49 \cdot 7$ & 0.91 & - & 一 \\
\hline $174 \cdot 6$ & $59 \cdot 7$ & 0.95 & - & - & $172 \cdot 7$ & $66 \cdot 8$ & 0.94 & - & - \\
\hline - & - & - & $4 \cdot 76$ & $0 \cdot 94$ & - & - & - & $3 \cdot 1$ & 0.99 \\
\hline - & - & - & - ve & $0 \cdot 01$ & - & - & - & - ve & $0 \cdot 13$ \\
\hline
\end{tabular}

Non-linear least squares analysis was used to obtain the $K_{\mathrm{m}(\mathrm{app})}$ and $V_{\max (\mathrm{app})}$ values. Linear regression analysis of the slope and intercept replots was used to obtain the $K_{\mathrm{i}(\mathrm{app})}$ values.

targeting, ephrin B1, a receptor tyrosine kinase ligand, and Jak1 tyrosine protein kinase.

Cauda A total of 38 genes changed a minimum of 2-fold in expression in the cauda epididymidis. Once again, transcripts involved in mediating or modulating signal transduction were differentially affected by inhibitor treatment (Fig. 8A). Rab-related GTP-binding protein and muscle/brain cAMP-dependent protein kinase inhibitor (PKI-alpha) showed the same dose-response profile where the maximum decrease in expression was achieved

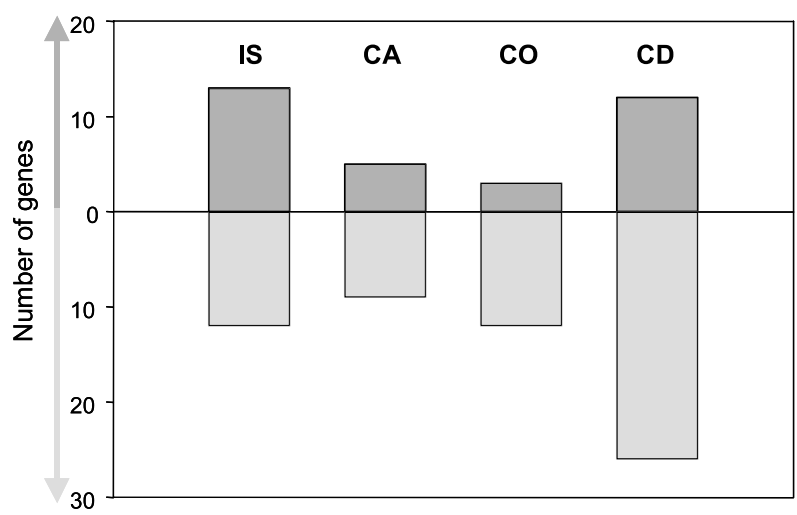

Figure 4 Number of genes in each epididymal segment showing changes in gene expression following $10 \mathrm{mg} / \mathrm{kg}$ per day PNU157706 treatment. The vertical scale represents the total number of genes that showed at least a 2-fold change in expression in either direction ( $100 \%$ increase or $50 \%$ decrease). The dark gray bars indicate the number of genes increasing in expression (above $x$-axis); the light gray bars indicate the number of genes decreasing in expression (below $x$-axis). IS, initial segment; $\mathrm{CA}$, caput; $\mathrm{CO}$, corpus, $\mathrm{CD}$, cauda. with the low dose of PNU157706. Transcripts for phosphatidylinositol 4-kinase (PI4-K) and the putative PKC regulatory protein, 14-3-3 protein gamma subtype, also similarly decreased in a dose-dependent manner with the maximum decrease achieved with the medium dose. The ras-related GTPase rab4B followed a different profile decreasing in a dose-dependent manner. In addition to these signaling genes, phospholipase expression was also affected. Phospholipases hydrolyze ester bonds in phospholipids to generate second messengers such as diacylglycerol and inositol triphosphate. Specifically in the cauda epididymidis, three phospholipase C (PLC) family members decreased in expression following PNU157706 treatment (Fig. 8B). PLC gamma-2, PLC delta-1 and PLC gamma-1 expression decreased in a dose-dependent manner, but the expression of the latter two genes was not affected by the low dose of PNU157706. Three different ion transporters decreased specifically in the cauda epididymidis (Fig. 8C). $\mathrm{H}^{+} / \mathrm{K}^{+}$-transporting ATPase alpha $2 \mathrm{a}$ subunit, implicated in the acidification of body fluids, decreased in expression maximally with the low dose of PNU157706. In contrast, the $\mathrm{Na}^{+} / \mathrm{K}^{+}$-transporting ATPase beta 2 subunit decreased in expression maximally only with the high dose of PNU157706. The anion exchanger, band 3 , which contributes to the regulation of cell $\mathrm{pH}$ and of cell volume, decreased in expression in a dose-dependent manner. Other genes that changed in expression specifically in the cauda epididymidis after inhibitor treatment included genes with metabolic functions (e.g. aldolase $\mathrm{C}$ and ceruloplasmin decreased), proteases (elastase 2 decreased, cathepsin $S$ increased) and growth-factor-related genes (e.g. platelet-derived growth factor receptor $\alpha$ and vascular endothelial growth factor D decreased). 
Table 2 Genes with minimum 2-fold changed expression in more than one epididymal segment following 10 mg/kg PNU157706 treatment

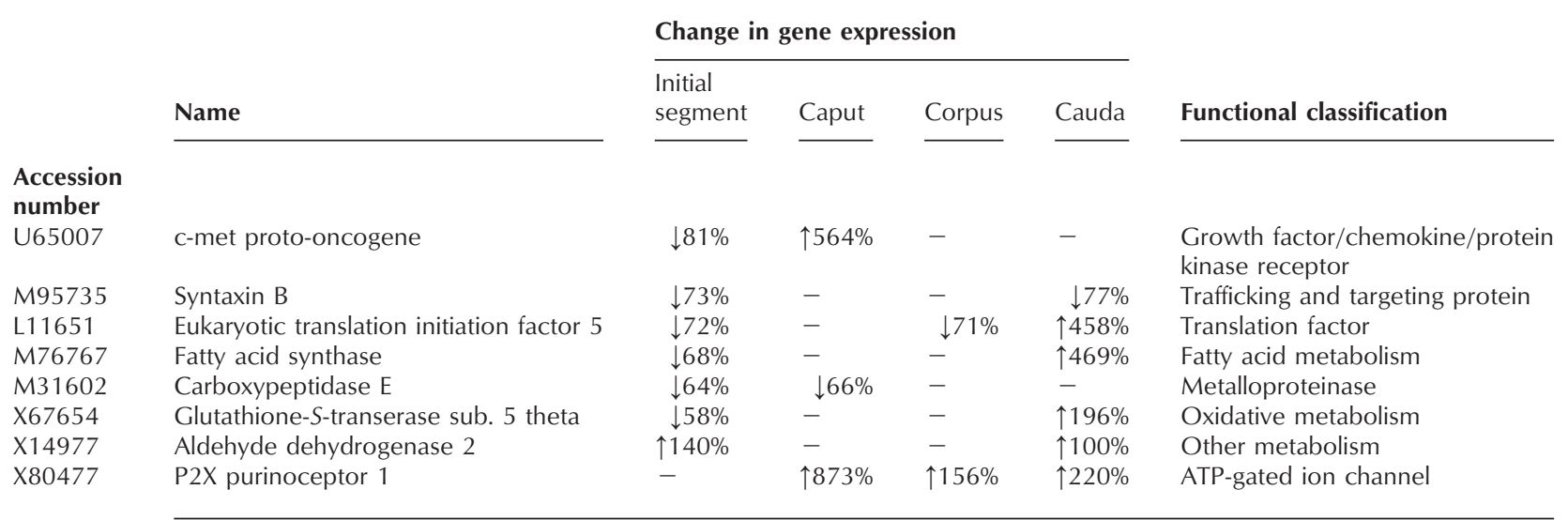

The arrows represent the direction of change in expression. The dash $(-)$ indicates no change in expression by 2 -fold or greater.

Accession numbers are for the GenBank database. Functional classifications are according to Clontech.

\section{Expression by gene family}

An advantage of cDNA array technology is the capability of examining the effects of $5 \alpha$-reductase inhibitor treatment on the overall expression of gene families that are known to be of importance in the epididymis. The expression patterns of two functionally relevant gene families, oxidative stress-related genes and proteasomal genes, were examined along the epididymis.

Oxidative stress-related genes The expression of four glutathione $S$-transferases (GSTs), one glutathione peroxidase (GPX) and glutathione synthetase (GSH synthetase) was examined along the epididymis following PNU157706 treatment (Fig. 9). GST mu expression decreased by $30 \%$ in the initial segment but remained unchanged in the other segments. GST Yrs-Yrs expression also decreased in the initial segment as well as in the cauda epididymidis by approximately 33 and 48\% respectively. In contrast, expression of this particular GST increased in the corpus by $2 \cdot 5$-fold. Interestingly, GST subunit 5 theta expression was also differentially affected by treatment in a segment-specific manner; expression decreased in the initial segment by $52 \%$ and increased in the cauda by 3 -fold. GST subunit 13 expression was decreased by $38 \%$ in the initial segment and by $67 \%$ in the corpus. Also changing in the initial segment was the expression of GPX3, which decreased 57\%. Lastly, the expression of GSH synthetase was increased specifically in the caput by approximately 1.6-fold. Clearly, the expression of oxidative stress-related genes was most affected in the proximal epididymis, particularly in the initial segment. Furthermore, with few exceptions, the predominant effect of treatment was decreased expression.

Proteasomal genes We examined the expression of eight proteasomal proteins along the epididymis following treatment with PNU157706 (Fig. 10). The predominant effect of treatment was a decrease in expression of the proteasomal genes, particularly in the distal epididymis (corpus and cauda epididymidis). Differential expression of the proteasomal genes was not observed in the initial segment. In this region, the greatest fold-change in expression was a 1.4-fold increase for proteasome component C3. Proteasomal gene transcript levels in the caput were also relatively unaffected by treatment with the exception of proteasome activator rPA28 subunit alpha that decreased $33 \%$ in expression and proteasome subunit RC10-II that decreased approximately $52 \%$ in expression. In the corpus epididymidis, transcript levels for proteasome subunit $\mathrm{R}$-delta, component $\mathrm{C} 8$, subunit $\mathrm{R}$-iota and -beta subunit decreased by approximately 33, 33, 63 and 30\% respectively. The greatest effect of treatment was seen in the cauda epididymidis. In this region, the greatest decrease in expression was observed for proteasome subunit rPA28 (69\%). Additionally, proteasome components C2 and C3 both decreased in expression by 33\% and proteasome component $\mathrm{C} 8$ and beta subunit decreased in expression by nearly $50 \%$.

\section{Discussion}

In the present study, we have confirmed that PNU157706 is a competitive inhibitor of microsomal and nuclear epididymal $5 \alpha$-reductase activity and has effects, in vivo, on the weights of DHT-dependent tissues, including the epididymis. Furthermore, we demonstrate that dual inhibition of $5 \alpha$-reductase has a highly segment-specific effect on the expression of a wide range of genes in the epididymis, thus indicating that DHT is a global mediator of many epididymal functions.

Perhaps the most important function of the epididymis is the creation of a continuously changing luminal 

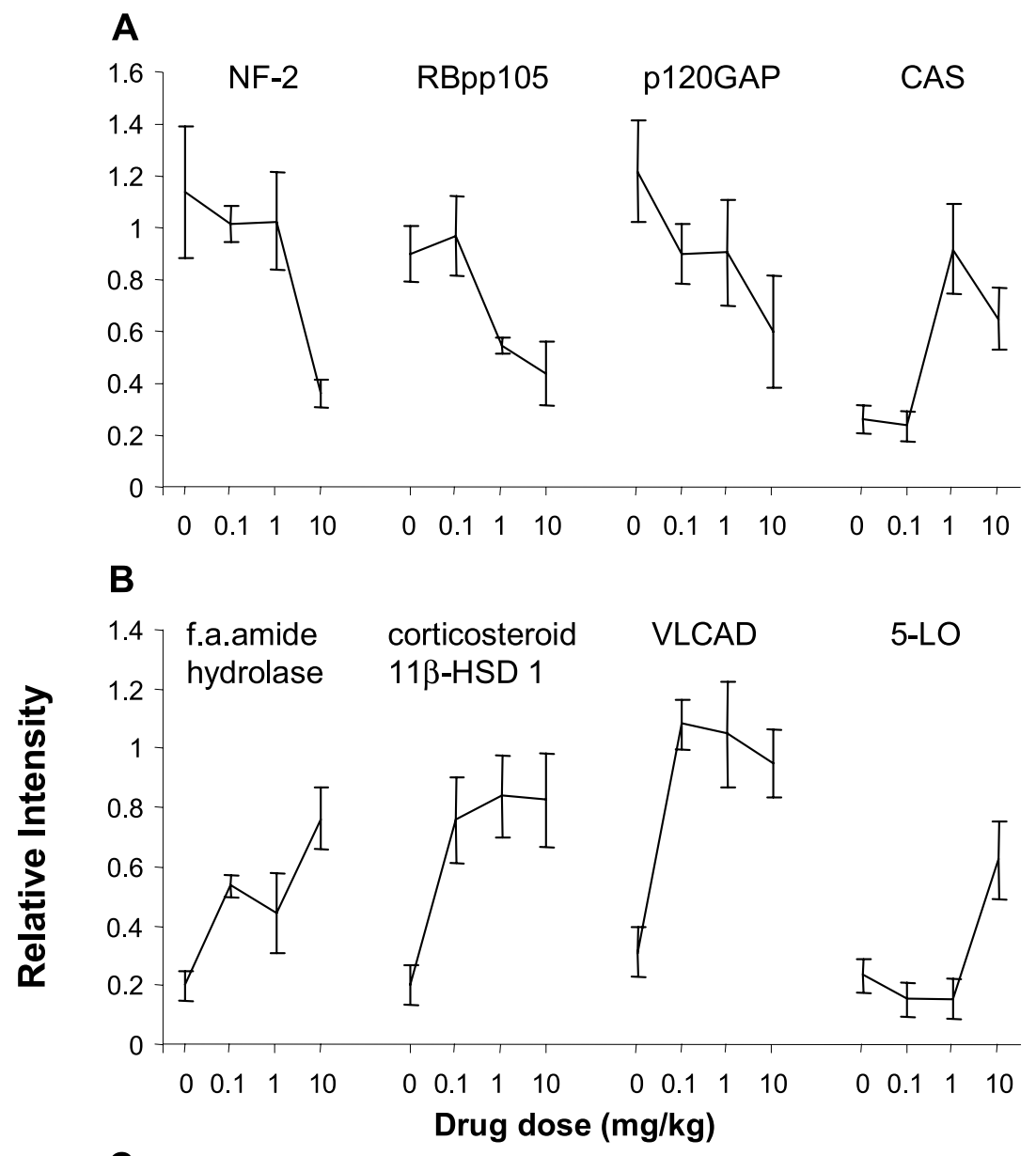

C

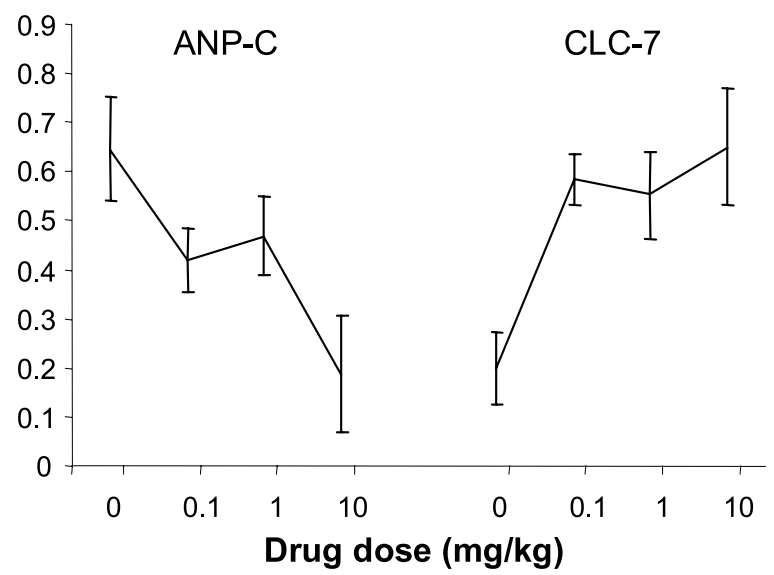

Figure 5 Genes with altered expression in the initial segment following PNU157706 treatment for 28 days. Each line represents one gene. (A) Signaling-related genes: NF-2, retinoblastoma protein pp105 (RBpp105), ras-GTPase activating protein (p120 GAP), Crk-associated substrate (CAS). (B) Fatty acid/lipid metabolism genes: fatty acid amide hydrolase (f.a. amide hydrolase), corticosteroid $11 \beta$-hydroxysteroid dehydrogenase (corticosteroid 11 $\beta$-HSD 1), very long chain acyl-CoA dehydrogenase (VLCAD), 5-lipoxygenase (5-LO). (C) Fluid/ion balance-related genes: atrial natriuretic peptide clearance receptor (ANP-C), chloride channel CLC-7 (CLC-7). Gene expression is presented as relative intensity (means \pm S.E.M., $3-5$ replicates/group) on the $y$-axis for each treatment group on the $x$-axis: control, $0 \mathrm{mg} / \mathrm{kg}(0) ; \mathrm{low}$ dose, $0 \cdot 1 \mathrm{mg} / \mathrm{kg}(0 \cdot 1)$; medium dose, $1 \cdot 0 \mathrm{mg} / \mathrm{kg}(1)$; high dose, $10 \mathrm{mg} / \mathrm{kg}(10)$. 


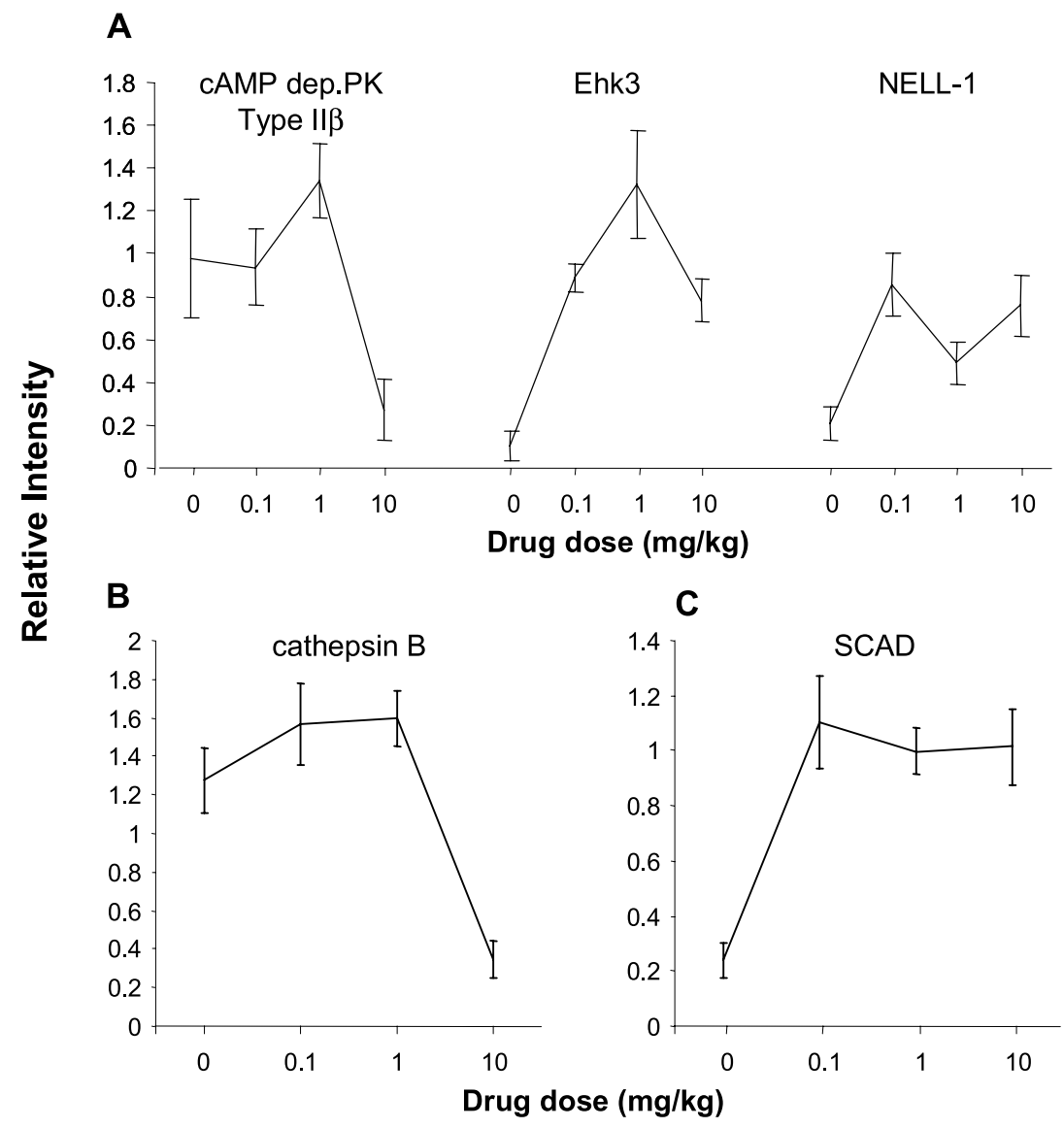

Figure 6 Genes with altered expression in the caput epididymidis following PNU157706 treatment for 28 days. Each line represents one gene. (A) Signaling-related genes: cAMP-dependent protein kinase type II-beta regulatory chain (cAMP dep. PK Type II $\beta$ ), Ehk3, and neural thrombospondin-like protein (NELL-1). (B) Cathepsin B. (C) Short chain acyl-CoA dehydrogenase (SCAD). Gene expression is presented as relative intensity (means \pm S.E.M., $3-5$ replicates/group) on the $y$-axis for each treatment group on the $x$-axis: control, $0 \mathrm{mg} / \mathrm{kg}(0) ;$ low dose, $0 \cdot 1 \mathrm{mg} / \mathrm{kg}(0 \cdot 1) ;$ medium dose, $1 \cdot 0 \mathrm{mg} / \mathrm{kg}(1)$; high dose, $10 \mathrm{mg} / \mathrm{kg}(10)$.

environment that allows for proper sperm concentration, maturation and storage in different segments of the epididymis (Turner 1991, Robaire \& Hinton 2002). A large number of studies have demonstrated that many of the individual processes that contribute to the creation of an optimal luminal microenvironment are regulated by androgens (Ezer \& Robaire 2002, 2003). These processes include fluid and ion transport, luminal acidification as well as protein and lipid secretion, processing and degradation. Our analysis of 2 -fold changes in gene expression following inhibitor treatment revealed the segmentspecific increase and decrease in expression of many genes potentially involved in these processes.

The major role of fluid transport across the epididymal epithelium is to concentrate sperm as they travel through the tubule. In addition, this process regulates the concentration of constituents in the luminal fluid to which sperm are exposed. Androgens influence fluid balance in the epididymis by regulating sodium and anion transport across the epithelium (Wong \& Yeung 1977, Au et al. 1978, Leung et al. 2002) and modulate the epididymal expression of specific aquaporins, water channels that mediate water transport in many tissues (Pastor-Soler et al. 2002). In this study, we have shown an effect of $5 \alpha$-reductase inhibition on the expression of several genes involved in fluid and ion transport. In the initial segment, expression of the clearance receptor for atrial natriuretic peptide decreased with treatment. This is of particular interest in light of the fact that atrial natriuretic peptide interacts physiologically with the renin-angiotensin system to control the fluid balance important for hemodynamic and renal function (Melo et al. 2000, Suzuki et al. 2001, Oliveira-Souza et al. 2002). Furthermore, in the epididymis, androgens regulate the expression of specific 

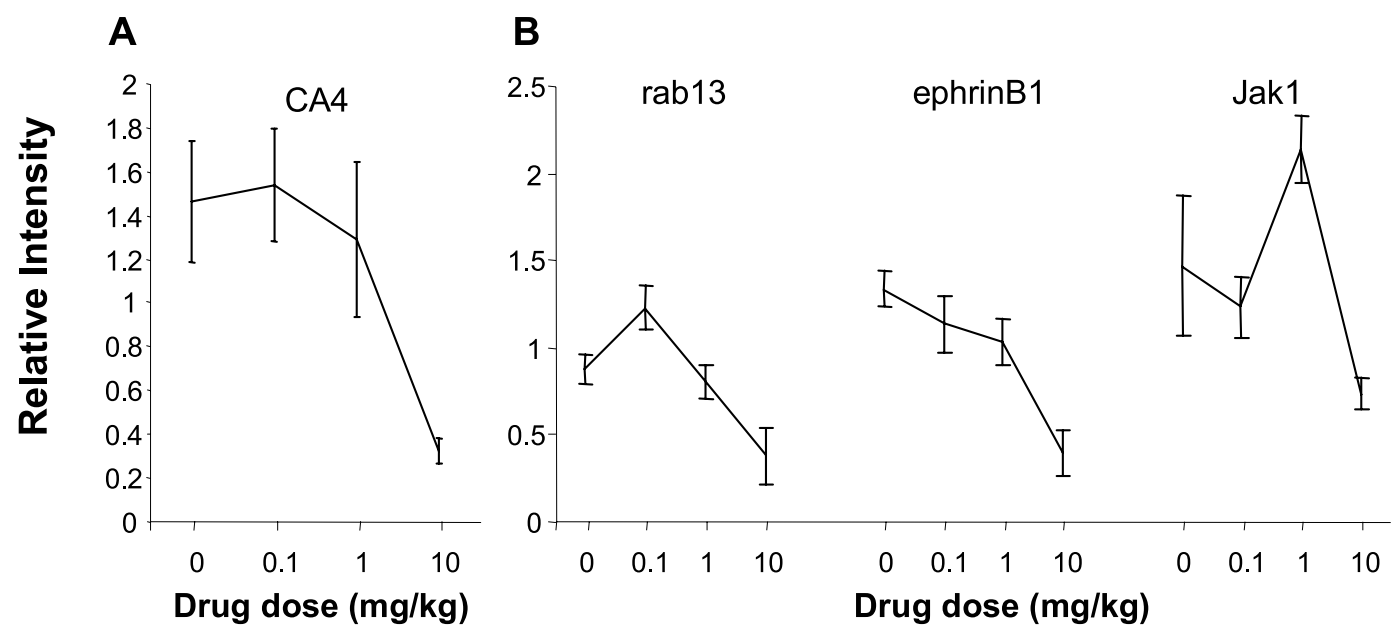

Figure 7 Genes with altered expression in the corpus epididymidis following PNU157706 treatment for 28 days. Each line represents one gene. (A) Carbonic anhydrase 4 (CA4). (B) Signaling-related genes: ras-related protein RAB13 (rab13), ephrinB1, and Jak1 tyrosine-protein kinase (Jak1). Gene expression is presented as relative intensity (means \pm S.E.M., $3-5$ replicates/group) on the $y$-axis for each treatment group on the $x$-axis: control, $0 \mathrm{mg} / \mathrm{kg}(0)$; low dose, $0 \cdot 1 \mathrm{mg} / \mathrm{kg}(0 \cdot 1)$; medium dose, $1 \cdot 0 \mathrm{mg} / \mathrm{kg}(1)$; high dose, $10 \mathrm{mg} / \mathrm{kg}(10)$.

components of the renin-angiotensin system, namely angiotensinogen and angiotensin II receptor type 1 (Leung et al. 2000, 2002). Thus, we propose that DHTdependent expression of specific components regulates this system mediating fluid transport in the epididymis.

Acidification of the luminal fluid is believed to be necessary for proper sperm maturation as well as storage, particularly in the distal epididymis (Turner \& Reich 1985). The anti-androgen flutamide has been shown to elevate epididymal luminal $\mathrm{pH}$ in rats, thus indicating that acidification is under the control of androgens (Caflisch 1993). Anion exchangers, ion channels, specific ATPases and carbonic anhydrase are implicated in the acidification process (Jensen et al. 1999, Kaunisto et al. 1999, Turner 2002). The mRNA for CA4, predominantly expressed in the corpus epididymidis, decreases following androgen withdrawal by castration (Kaunisto et al. 1999). In the present study, CA4 is also shown to be expressed predominantly in the corpus epididymidis. Furthermore, CA4 showed the highest fold decrease in expression with inhibitor treatment, specifically in this segment, suggesting that the androgen regulating the expression of this gene is DHT. In the cauda epididymidis, we describe a further effect of inhibitor treatment on the expression of two other genes involved in $\mathrm{pH}$ regulation; the expression of the alpha 2a subunit of the $\mathrm{H}^{+} / \mathrm{K}^{+}$-transporting ATPase decreased as did that of band 3 anion exchanger.

Sequential exposure of sperm to epididymal luminal contents, including proteins, is necessary for proper maturation (Turner 1991). While fluid regulation ensures the right quantity of proteins present in the epididymal lumen, the qualitative evolution of proteins along the tubule involves protein processing and degradation events.
Furthermore, protein processing is required for direct modification of sperm surface proteins, a major feature of epididymal sperm maturation (Phelps et al. 1990, Jones 1998). Some of the genes showing the highest fold segment-specific changes in expression following inhibitor treatment are those involved in protein processing/ degradation (cathepsin B, elastase 2, serine proteinase rPC7), suggesting that DHT is an important regulator of this function. Of these three genes, only cathepsin B has been characterized previously in the epididymis at the protein and enzyme activity levels (Tomomasa et al. 1994, Igdoura et al. 1995). Notably, elastase 2 has angiotensin II forming ability (Santos et al. 2002) and might therefore represent another DHT-regulated component of the renin-angiotensin system in the epididymis.

A striking effect of inhibitor treatment was the increased expression of five genes involved in fatty acid/lipid metabolism in the proximal epididymis. These results are not altogether surprising since the epididymal lumen is a lipid-rich environment and the modification and exchange of sperm membrane lipids is another major feature of sperm maturation occurring in the proximal epididymis (Jones 1998). Interestingly, modification of the phospholipid environment regulates $5 \alpha$-reductase activity (Cooke \& Robaire 1985). Lipid-metabolizing enzymes have been shown previously to be androgen-regulated in the prostate (Swinnen et al. 1997) and the epididymis (Beck 1980). Our results suggest that DHT regulates lipid metabolism by endogenously repressing the expression of specific enzymes.

An important advantage of gene expression profiling is the ability to analyze, in an integrated way, the expression of genes that carry out important functions as well as genes 

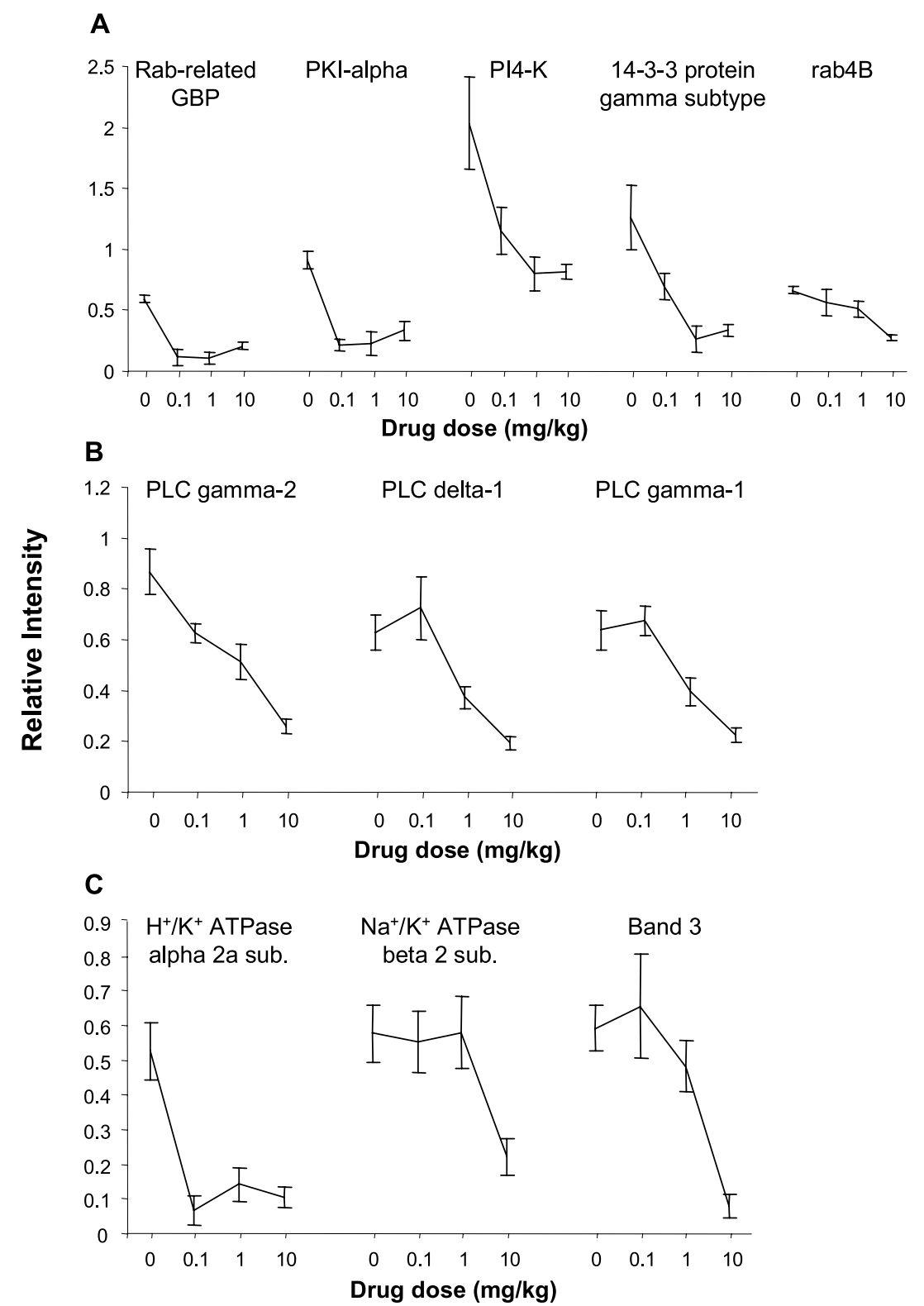

Figure 8 Genes with altered expression in the cauda epididymidis following PNU157706 treatment $(10 \mathrm{mg} / \mathrm{kg})$ for 28 days. Each line represents one gene. (A) Signaling-related genes: Rab-related GTP-binding protein (Rab-related GBP), muscle/brain cAMP-dependent protein kinase inhibitor ( $\mathrm{PKI}$-alpha), phosphatidylinositol 4-kinase (PI4-K), 14-3-3 protein gamma subtype, and ras-related GTPase rab4B (rab4B). (B) Phospholipase genes:

phospholipase C gamma 2 (PLC gamma-2), phospholipase C delta 1 (PLC delta-1), and phospholipase $\mathrm{C}$ gamma 1 (PLC gamma-1). (C) lon-transporter genes: $\mathrm{H}^{+} / \mathrm{K}^{+}$-transporting ATPase alpha 2a subunit $\left(\mathrm{H}^{+} / \mathrm{K}^{+}\right.$ATPase alpha 2a sub.), $\mathrm{Na}^{+} / \mathrm{K}^{+}$-transporting ATPase beta 2 subunit $\left(\mathrm{Na}^{+} / \mathrm{K}^{+}\right.$ATPase beta 2 sub.), and band 3 anion exchanger (Band 3). Gene expression is presented as relative intensity (means \pm S.E.M., $3-5$ replicates/group) on the $y$-axis for each treatment group on the $x$-axis: control, $0 \mathrm{mg} / \mathrm{kg}(0)$; low dose, $0.1 \mathrm{mg} / \mathrm{kg}$ $(0 \cdot 1)$; medium dose, $1 \cdot 0 \mathrm{mg} / \mathrm{kg}(1)$; high dose, $10 \mathrm{mg} / \mathrm{kg}(10)$.

that regulate these functions. Inhibitor treatment clearly has a segment-specific effect on the expression of genes involved in signal transduction, indicating possible mechanisms through which DHT signals to promote sperm-related functions. For example, the PKC-binding protein, NELL-1, increased in expression in the caput 


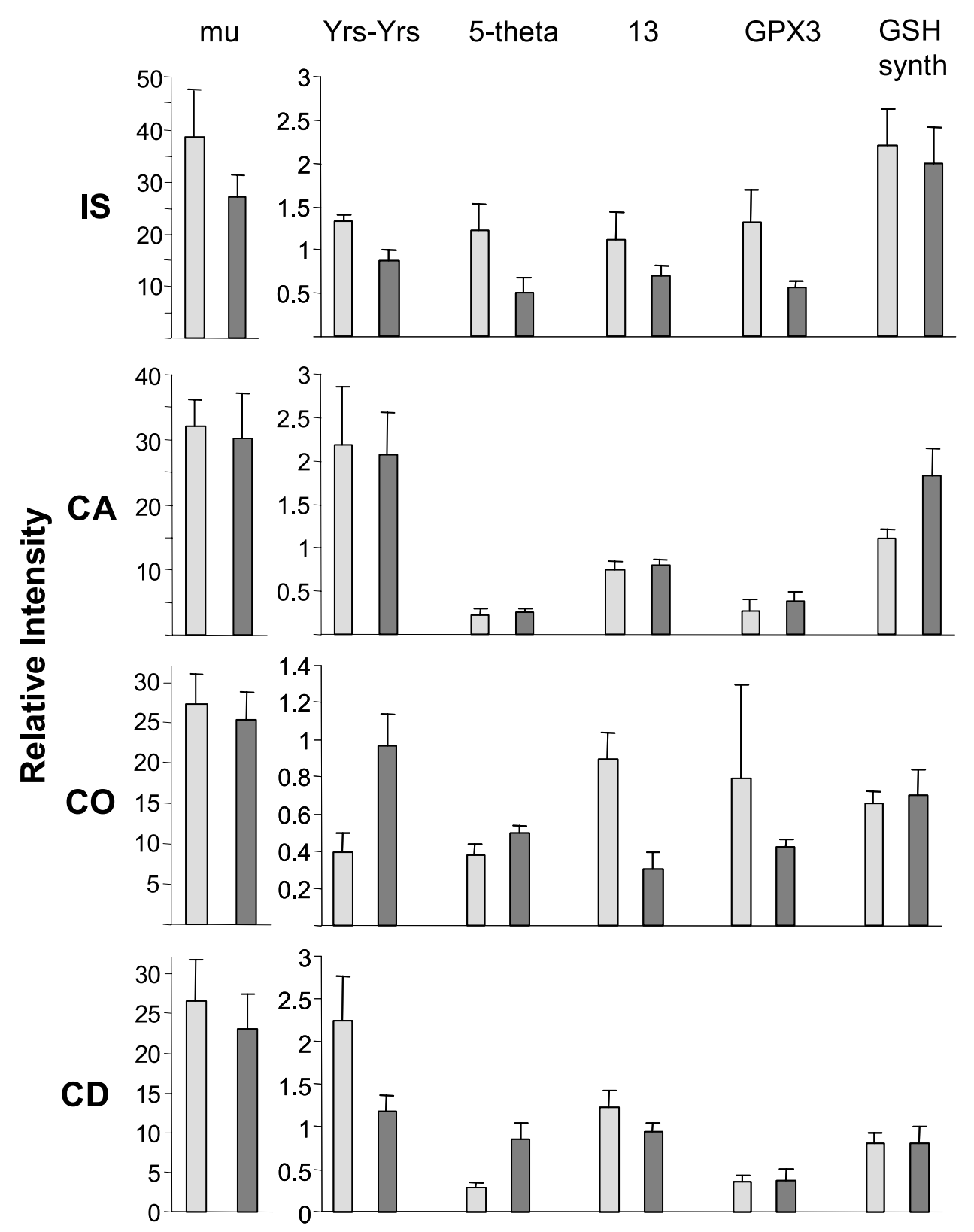

Figure 9 Expression of oxidative stress-related genes in the control (light gray bars) and high PNU157706 treatment (dark gray bars, $10 \mathrm{mg} / \mathrm{kg}$ per day) groups in the initial segment (IS), caput (CA), corpus $(\mathrm{CO})$ and cauda $(\mathrm{CD})$ epididymidis. Gene expression is presented as relative intensity (means \pm S.E.M., 3-5 replicates/group) on the $y$-axis for each specific gene on the $x$-axis: GST mu (mu), GST Yrs-Yrs (Yrs-Yrs), GST subunit 5-theta (5-theta), GST subunit 13 (13), GPX3, and glutathione synthetase (GSH synth).

epididymidis, while expression of 14-3-3 protein gamma subtype, a PKC regulator, decreased in the cauda epididymidis. The PKC family is interesting as various important PKC isoforms have been shown to be androgenregulated in the rat ventral prostate (Montalvo et al. 2002). Inhibitor treatment also altered the expression of several ras/rab-related genes in a segment-specific way. These are members or regulators of the small G-protein superfamily that mediates cellular processes such as cytoskeletal reorganization, vesicular and nuclear transport, and notably, gene expression (Paduch et al. 2001). An example of one such gene is rab13, which decreased in expression in the 


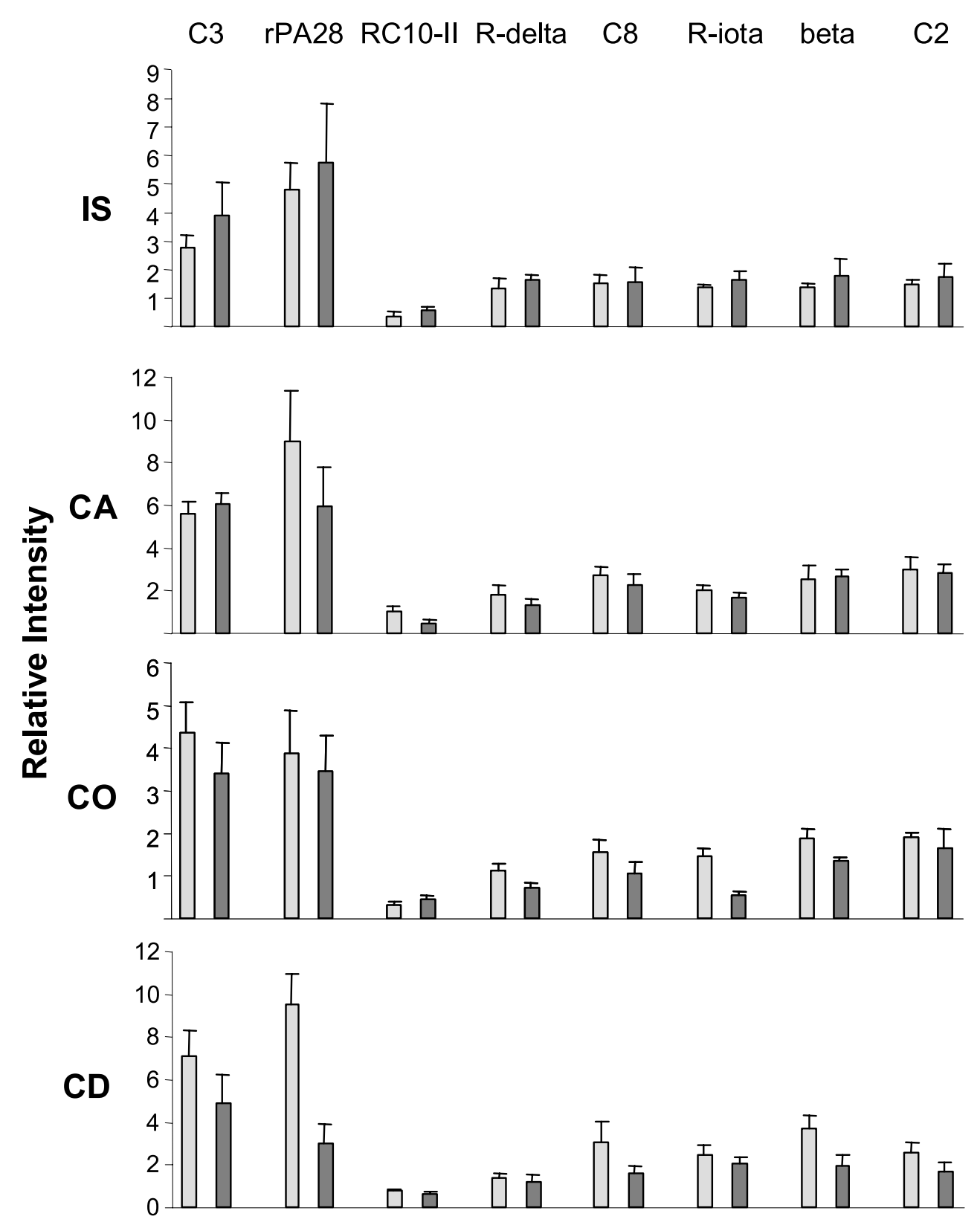

Figure 10 Expression of proteasomal genes in the control (light gray bars) and high PNU157706 treatment (dark gray bars, $10 \mathrm{mg} / \mathrm{kg}$ per day) groups in the initial segment (IS), caput (CA), corpus (CO) and cauda (CD) epididymidis. Gene expression is presented as relative intensity (means \pm S.E.M., $3-5$ replicates/group) on the $y$-axis for each specific gene on the $x$-axis: proteasome component $\mathrm{C} 3(\mathrm{C} 3)$, proteasome activator rPA28 subunit alpha (rPA28), proteasome subunit RC10-II (RC10-II), proteasome subunit R-delta (R-delta), proteasome component C8 (C8), proteasome subunit R-iota (R-iota), proteasome subunit-beta (beta), and proteasome component $\mathrm{C} 2(\mathrm{C} 2)$.

corpus epididymidis following inhibitor treatment. DHTdependent regulation of this gene is of note because rab13 has been shown to regulate the assembly of functional tight junctions in epithelial cells (Marzesco et al. 2002) and androgens are known to regulate components of tight junctions in epithelial cells of the epididymis (Cyr et al. 1996, Gregory et al. 2001). Tight junctions are important components of occluding barriers, including the blood-epididymis barrier, which enables the creation of the optimal luminal microenvironment.

In addition to their functional relevance in the epididymis, lipids also play key roles in signaling 
(Cantley 2002). Inhibitor treatment decreased the expression of three PLC enzymes specifically in the cauda epididymidis. Phosphoinositides are classic signaling lipids and the importance of phospholipases in regulating phosphoinositide metabolism has been well characterized. More recently, a role for lipids in nuclear signal transduction has emerged that requires the activation of PLC (Dygas \& Baranska 2001). This nuclear location has implications for direct control of gene expression (Dygas \& Baranska 2001, Martelli et al. 2002). DHT-dependent regulation of PLC expression might therefore indirectly control the expression of other important genes.

Spermatozoa generate reactive oxygen species required for capacitation and chromatin condensation; however, spermatozoa are also highly susceptible to the damaging effects of reactive oxygen species (Aitken 2002). Antioxidant defense mechanisms are thus of great importance in the epididymis to protect maturing spermatozoa as well as the epididymal epithelium from oxidative damage. Orchidectomy and androgen replacement studies demonstrate that the epididymal GSTs are under separate control and are differentially regulated by androgens (Robaire \& Hales 1982). Our results further support the importance of DHT in regulating enzymes of the glutathione cycle, predominantly in the proximal epididymis where the glutathione antioxidant enzymes are concentrated.

The key function of the proteasome, a large, multicatalytic protease, is protein degradation (Coux et al. 1996, DeMartino \& Slaughter 1999). In the epididymis, controlled protein degradation via the proteasome pathway not only regulates the luminal protein repertoire and contributes to sperm membrane remodeling during maturation, it also provides an important secondary defense against oxidative stress by preventing the accumulation of oxidized and damaged proteins (Grune 2000, Mehlhase \& Grune 2002). Furthermore, the regulated degradation of proteins is involved in the control of various signal transduction pathways (Callis \& Vierstra 2000). The overwhelming effect of inhibitor treatment was a decrease in proteasomal gene expression predominantly in the corpus and cauda epididymidis, implying that proteasomal gene expression is DHT-dependent in these two segments. Of particular relevance is a recent study in prostate cancer cells indicating an important role of the proteasome system in the regulation of androgen receptor transcriptional activity (Lin et al. 2002). Evidence suggests that the proteasome exerts its regulatory role by affecting androgen receptor transactivation, nuclear translocation, degradation and interaction with coregulators. Thus, it is also plausible that regulation of proteasomal gene expression by DHT affects the downstream expression of other androgen-dependent genes in the epididymis.

In summary, our study of the effects of $5 \alpha$-reductase inhibition on gene expression in the epididymis has shown DHT to be a major regulator of the segment-specific expression of a wide array of genes and gene families. The nature of the genes affected enhances our understanding of the androgen-regulated processes contributing to optimal sperm maturation in this tissue. Several novel genes were identified and further investigation is required to determine their functional relevance and potential as therapeutic targets in the control of male fertility and contraception.

\section{Acknowledgements}

We should like to thank Dr T Zaccheo from PharmaciaUpjohn (presently Pfizer) for a generous gift of PNU157706.

\section{Funding}

$\mathrm{NAH}$ is a recipient of a Canadian Institutes of Health Research Studentship. These studies were entirely funded by the CIHR (Canada). No financial contribution was received by the authors from private sources.

\section{References}

Aitken RJ 2002 Active oxygen in spermatozoa during epididymal transport. In The Epididymis: From molecules to Clinical Practice, pp 435-447. Eds B Robaire \& BT Hinton. New York: Kluwer Academic/Plenum Publishers.

Andersson S \& Russell DW 1990 Structural and biochemical properties of cloned and expressed human and rat steroid 5-alpha-reductases. PNAS 87 3640-3644.

Au CL, Ngai HK, Yeung CH \& Wong PY 1978 Effect of adrenalectomy and hormone replacement on sodium and water transport in the perfused rat cauda epididymidis. Journal of Endocrinology $77265-266$.

Bartsch G, Rittmaster RS \& Klocker H 2002 Dihydrotestosterone and the concept of 5 alpha-reductase inhibition in human benign prostatic hyperplasia. World Journal of Urology 19 413-425.

Beck B 1980 Tissue-specificity of the epididymal androgen dependent phospholipase-A. International Journal of Andrology 3 349-362.

Blaquier JA, Burgos MH \& Cameo MS 1972 Role of androgens in maturation of epididymal spermatozoa in guinea-pig. Endocrinology $90839-842$.

Caflisch CR 1993 Effect of a nonsteroidal antiandrogen, flutamide on intraluminal acidification in rat testis and epididymis. Andrologia $\mathbf{2 5}$ 363-367.

Callis J \& Vierstra RD 2000 Protein degradation in signaling. Current Opinion in Plant Biology 3 381-386.

Cantley LC 2002 The phosphoinositide 3-kinase pathway. Science 296 $1655-1657$.

Cohen J, Ooms MP \& Vreeburg JTM 1981 Reduction of fertilizing capacity of epididymal spermatozoa by 5 -alpha-steroid reductase inhibitors. Experientia 37 1031-1032.

Cooke GM \& Robaire B 1985 Modulation of epididymal delta-4steroid 5 -alpha-reductase activity in vitro by the phospholipid environment. Journal of Biological Chemistry 260 7489-7495.

Cooke GM \& Robaire B 1986 The effects of diethyl-4-methyl-3-oxo4-aza-5-alpha-androstane-17-beta-carboxamide (4-Ma) and (4R)-5,10-seco-19-norpregna-4,5-diene-3,10,20-trione (Seco) on androgen biosynthesis in the rat testis and epididymis. Journal of Steroid Biochemistry 24 877-886. 
Cooke GM \& Robaire B 1987 The mechanism of rat epididymal 4-ene steroid 5-alpha-reductase. Journal of Steroid Biochemistry and Molecular Biology 26 361-368.

Cornwall GA, Lareyre JJ, Matusik RJ, Hinton BT \& Orgebin-Crist MC 2002 Gene expression and epididymal function. In The Epididymis: From Molecules to Clinical practice, pp 169-199. Eds B Robaire \& BT Hinton. New York: Kluwer Academic/Plenum Publishers.

Coux O, Tanaka K \& Goldberg AL 1996 Structure and functions of the $20 \mathrm{~S}$ and 26S proteasomes. Annual Review of Biochemistry 65 801-847.

Cyr DG, Hermo L \& Laird DW 1996 Immunocytochemical localization and regulation of connexin 43 in the adult rat epididymis. Endocrinology 137 1474-1484.

de Larminat MA \& Blaquier JA 1979 Effect of in vivo administration of 5 alpha reductase inhibitors on epididymal function. Acta Physiologica Latin America 29 1-6.

DeMartino GN \& Slaughter CA 1999 The proteasome, a novel protease regulated by multiple mechanisms. Journal of Biological Chemistry 274 22123-22126.

Dygas A \& Baranska J 2001 Lipids and signal transduction in the nucleus. Acta Biochimica Polonica 48 541-549.

Ezer N \& Robaire B 2002 Androgen regulation of epididymal structure and function. In The Epididymis: From Molecules to Clinical Practice, pp 297-316. Eds B Robaire \& BT Hinton. New York: Kluwer Academic/Plenum Publishers.

Ezer N \& Robaire B 2003 Gene expression is differentially regulated in the epididymis after orchidectomy. Endocrinology 144 977-988.

Gloyna RE \& Wilson JD 1969 A comparative study of the conversion of testosterone to $17 \beta$-hydroxy- $5 \alpha$-androstan-3-one (dihydrotestosterone) by rat prostate and epididymis. Journal of Clinical Endocrinology and Metabolism 29 970-977.

Gregory M, Dufresne J, Hermo L \& Cyr DG 2001 Claudin-1 is not restricted to tight junctions in the rat epididymis. Endocrinology 142 854-863.

Grune T 2000 Oxidative stress, aging and the proteasomal system. Biogerontology 1 31-40.

Herwig R, Aanstad P, Clark M \& Lehrach H 2001 Statistical evaluation of differential expression on cDNA nylon arrays with replicated experiments. Nucleic Acids Research 29 e117.

Hess RA, Zhou Q \& Nie R 2002 The role of estrogens in the endocrine and paracrine regulation of the efferent ductules, epididymis and vas deferens. In The Epididymis: From Molecules to Clinical Practice, pp 317-337. Eds B Robaire \& BT Hinton. New York: Kluwer Academic/Plenum Publishers.

Hinton BT, Lan ZJ, Rudolph DB, Labus JC \& Lye RJ 1998 Testicular regulation of epididymal gene expression. Journal of Reproduction and Fertility 53 (Suppl) 47-57.

Igdoura SA, Morales CR \& Hermo L 1995 Differential expression of cathepsin-B and cathepsin-D in testis and epididymis of adult rats. Journal of Histochemistry and Cytochemistry 43 545-557.

Jensen LJ, Stuart-Tilley AK, Peters LL, Lux SE, Alper SL \& Breton S 1999 Immunolocalization of AE2 anion exchanger in rat and mouse epididymis. Biology of Reproduction 61 973-980.

Jervis KM \& Robaire B 2001 Dynamic changes in gene expression along the rat epididymis. Biology of Reproduction 65 696-703.

Jervis KM \& Robaire B 2002 Changes in gene expression during aging in the Brown Norway rat epididymis. Experimental Gerontology 37 897-906.

Jervis KM \& Robaire B 2003 Effects of caloric restriction on gene expression along the epididymis of the Brown Norway rat during aging. Experimental Gerontology 38 549-560.

Jones R 1998 Plasma membrane structure and remodelling during sperm maturation in the epididymis. Journal of Reproduction and Fertility 53 (Supp 1) 73-84.

Kaunisto K, Fleming RE, Kneer J, Sly WS \& Rajaniemi H 1999 Regional expression and androgen regulation of carbonic anhydrase IV and II in the adult rat epididymis. Biology of Reproduction $\mathbf{6 1}$ 1521-1526.
Lan ZJ, Labus JC \& Hinton BT 1998 Regulation of gamma-glutamyl transpeptidase catalytic activity and protein level in the initial segment of the rat epididymis by testicular factors: role of basic fibroblast growth factor. Biology of Reproduction 58 197-206.

Lee MLT, Kuo FC, Whitmore GA \& Sklar J 2000 Importance of replication in microarray gene expression studies: statistical methods and evidence from repetitive cDNA hybridizations. PNAS $\mathbf{9 7}$ 9834-9839.

Leung PS, Wong TP, Lam SY, Chan HC \& Wong PYD 2000 Testicular hormonal regulation of the renin-angiotensin system in the rat epididymis. Life Sciences 66 1317-1324.

Leung PS, Wong TP, Chung YW \& Chan HC 2002 Androgen dependent expression of AT1 receptor and its regulation of anion secretion in rat epididymis. Cell Biology International 26 117-122.

Li X, Chen CL, Singh SM \& Labrie F 1995 The enzyme and inhibitors of 4-ene-3-oxosteroid 5-alpha-oxidoreductase. Steroids $\mathbf{6 0}$ 430-441.

Lin HK, Altuwaijri S, Lin WJ, Kan PY, Collins LL \& Chang C 2002 Proteasome activity is required for androgen receptor transcriptional activity via regulation of androgen receptor nuclear translocation and interaction with coregulators in prostate cancer cells. Journal of Biological Chemistry 277 36570-36576.

Lowry OF, Rosebrough NJ, Farr AL \& Randall RJ 1951 Protein estimation with the Folin phenol reagent. Journal of Biological Chemistry 193 265-271.

Martelli AM, Bortul R, Tabellini G, Bareggi R, Manzoli L, Narducci P \& Cocco L 2002 Diacylglycerol kinases in nuclear lipid-dependent signal transduction pathways. Cellular and Molecular Life Sciences 59 1129-1137.

Marzesco AM, Dunia I, Pandjaitan R, Recouvreur M, Dauzonne D, Benedetti EL, Louvard D \& Zahraoui A 2002 The small GTPase Rab13 regulates assembly of functional tight junctions in epithelial cells. Molecular Biology of the Cell 13 1819-1831.

McGrath ME 1999 The lysosomal cysteine proteases. Annual Review of Biophysics and Biomolecular Structure 28 181-204.

Mehlhase J \& Grune T 2002 Proteolytic response to oxidative stress in mammalian cells. Biological Chemistry 383 559-567.

Melo LG, Pang SC \& Ackermann U 2000 Atrial natriuretic peptide: regulator of chronic arterial blood pressure. News in Physiological Sciences 15 143-149.

Montalvo L, Sanchez-Chapado M, Prieto JC \& Carmena MJ 2002 Regulation of the expression of protein kinase $\mathrm{C}$ isoenzymes in rat ventral prostate: effects of age, castration and flutamide treatment. Life Sciences 71 2257-2266.

Normington K \& Russell DW 1992 Tissue distribution and kinetic characteristics of rat steroid 5-alpha-reductase isozymes - evidence for distinct physiological functions. Journal of Biological Chemistry 267 19548-19554.

Oliveira-Souza M, Malnic G \& Mello-Aires M 2002 Atrial natriuretic peptide impairs the stimulatory effect of angiotensin II on $\mathrm{H}^{+}$-ATPase. Kidney International 62 1693-1699.

Orgebin-Crist MC 1967 Sperm maturation in rabbit epididymis. Nature 216 816-818.

Orgebin-Crist MC \& Tichenor PL 1973 Effect of testosterone on sperm maturation in vitro. Nature 245 328-329.

Orgebin-Crist MC, Jahad N \& Hoffman LH 1976 Effects of testosterone, 5-alpha-dihydrotestosterone, 3-alpha-androstanediol, and 3-beta-androstanediol on maturation of rabbit epididymal spermatozoa in organ-culture. Cell and Tissue Research 167 515-525.

Orgebin-Crist MC, Lareyre JJ, Suzuki K, Araki Y, Fouchecourt S, Matusik RJ \& Ong DE 2002 Retinoids and epididymal function. In The Epididymis: From Molecules to Clinical Practice, pp 339-352. Eds B Robaire \& BT Hinton. New York: Kluwer Academic/Plenum Publishers.

Paduch M, Jelen F \& Otlewski J 2001 Structure of small G proteins and their regulators. Acta Biochimica Polonica 48 829-850. 
Pastor-Soler L, Isnard-Bagnis C, Herak-Kramberger C, Sabolic I, Van Hoek A, Brown D \& Breton S 2002 Expression of aquaporin 9 in the adult rat epididymal epithelium is modulated by androgens. Biology of Reproduction 66 1716-1722.

Phelps BM, Koppel DE, Primakoff P \& Myles DG 1990 Evidence that proteolysis of the surface is an initial step in the mechanism of formation of sperm cell-surface domains. Journal of Cell Biology 111 1839-1847.

Robaire B \& Hales BF 1982 Regulation of epididymal glutathione $S$-transferases - effects of orchidectomy and androgen replacement. Biology of Reproduction 26 559-565.

Robaire B \& Hinton BT 2002 (eds) The Epididymis: From Molecules to Clinical Practice. New York; Kluwer Academic/Plenum Publishers.

Robaire B \& Viger RS 1993 Regulation of epididymal epithelial cell functions. In Understanding Male Infertility: Basic and Clinical Approaches, pp 183-210. Eds RW Whitcomb \& B Zirkin. New York: Raven Press.

di Salle E, Briatico G, Giudici D, Ornati G \& Panzeri A 1994 Endocrine properties of the testosterone 5-alpha-reductase inhibitor turosteride (Fce-26073). Journal of Steroid Biochemistry 48 241-248.

di Salle E, Giudici D, Radice A, Zaccheo T, Ornati G, Nesi M, Panzeri A, Delos S \& Martin PM 1998 PNU157706, a novel dual type I and II 5 alpha-reductase inhibitor. Journal of Steroid Biochemistry and Molecular Biology 64 179-186.

Santos CF, Oliveira EB, Salgado MCO \& Greene AS 2002 Molecular cloning and sequencing of the cDNA for rat mesenteric arterial bed elastase-2, an angiotensin II-forming enzyme. Journal of Cardiovascular Pharmacology 39 628-635.

Steers WD 2001 5-Alpha-reductase activity in the prostate. Urology $\mathbf{5 8}$ (Suppl 1) 17-24.

Strittmatter SM \& Snyder SH 1984 Angiotensin-converting enzyme in the male rat reproductive system: autoradiographic visualization with $\left[{ }^{3} \mathrm{H}\right]$ captopril. Endocrinology 115 2332-2341.

Sudduth SL, Koronkowski MJ, Sharifi R, Lee M, Cali TJ \& Chamberlain TM 1993 Finasteride - the first 5-alpha-reductase inhibitor. Pharmacotherapy 13 309-329.

Suzuki T, Yamazaki T \& Yazaki Y 2001 The role of the natriuretic peptides in the cardiovascular system. Cardiovascular Research $\mathbf{5 1}$ 489-494.

Swinnen JV, Ulrix W, Heyns W \& Verhoeven G 1997 Coordinate regulation of lipogenic gene expression by androgens: evidence for a cascade mechanism involving sterol regulatory element binding proteins. PNAS 94 12975-12980.

Tindall DJ, Nayfeh SN \& French FS 1972 Androgen uptake and binding in rat epididymal nuclei, in-vivo. Biochemical and Biophysical Research Communications 49 1391-1397.

Tomomasa H, Waguri S, Umeda T, Koiso K, Kominami E \& Uchiyama Y 1994 Lysosomal cysteine proteinases in rat epididymis. Journal of Histochemistry and Cytochemistry 42 417-425.

Turner TT 1991 Spermatozoa are exposed to a complex microenvironment as they traverse the epididymis. Annals of the New York Academy of Sciences 637 364-383.

Turner TT 2002 Necessity's potion: inorganic ions and small organic molecules in the epididymal lumen. In The Epididymis: From Molecules to Clinical Practice, pp 131-150. Eds B Robaire \& BT Hinton. New York: Kluwer Academic/Plenum Publishers.

Turner TT \& Reich GW 1985 Cauda epididymal sperm motility: a comparison among five species. Biology of Reproduction 32 $120-128$.

Turner TT, Jones CE, Howards SS, Ewing LL, Zegeye B \& Gunsalus GL 1984 On the androgen microenvironment of maturing spermatozoa. Endocrinology 115 1925-1932.

Viger RS \& Robaire B 1996 The mRNAs for the steroid 5 alpha-reductase isozymes, types 1 and 2 , are differentially regulated in the rat epididymis. Journal of Andrology 17 27-34.

Wilkinson GN 1961 Statistical estimations in enzyme kinetics. Biochemical Journal 80 324-332.

Wong PYD \& Yeung CH 1977 Hormonal regulation of fluid reabsorption in isolated rat cauda epididymidis. Endocrinology 101 1391-1397.

Zoppi S, Lechuga M \& Motta M 1992 Selective inhibition of the 5-alpha-reductase of the rat epididymis. Journal of Steroid Biochemistry and Molecular Biology 42 509-514.

Received 4 November 2003

Accepted 10 February 2004

Made available online as an

Accepted Preprint 13 February 2004 